\title{
CARDIOPROTECTIVE EFFECT OF PHYLLANTHUS FRATERNUS LEAVES EXTRACT AGAINST CYCLOPHOSPHAMIDE - INDUCED MYOCARDIAL INJURY IN RATS
}

\author{
RAKESH SINGH MOIRANGTHEM ${ }^{1}$, NGANGOM GUNINDRO ${ }^{1}$, DIPDEBA SINGH TAKHELLAMBAM르, \\ SUCHETA DEVI KHURAIJAM ${ }^{2}$, MEENA N ${ }^{1}$, RITA ${ }^{1}$
}

${ }^{1}$ Department of Pharmacology, Regional Institute of Medical Sciences, Imphal, Manipur, India. ${ }^{2}$ Department of Pathology, Regional Institute of Medical Sciences, Imphal, Manipur, India. Email: rakesmoir@gmail.com

Received: 28 June 2017, Revised and Accepted: 26 August 2017

ABSTRACT

Objectives: This study was undertaken to investigate the possible protective effect of aqueous extract of Phyllanthus fraternus (AEPF) leaves against cyclophosphamide (CP) induced myocardial toxicity in rats.

Methods: Wistar rats were given CP single intraperitoneally injection (200 mg/kg) on day 1 of the experiment and two doses of AEPF (200 mg/kg and $400 \mathrm{mg} / \mathrm{kg}$ ) p.o. daily for 10 days. Cardiac biomarker enzymes such as creatinine kinase (CK), CK isoenzyme MB, lactate dehydrogenase, alkaline phosphatase, alanine transaminase, and aspartate transaminase were determined. Histopathological examinations of the hearts were done.

Results: CP treated groups exhibited significantly increased in cardiac biomarker enzymes. Treatment with AEPF prevented the elevation of these enzymes. Potential protective effect was also seen in histopathological examination of the heart characterized by decreased myocardium cell damages in AEPF treatment group.

Conclusion: The study showed the protective role of AEPF against CP-induced myocardial injury. The possible role of antioxidant activity is anticipated.

Keywords: Phyllanthus fraternus, Cyclophosphamide, Cardiotoxicity, Cardiac biomarkers, Histopathological.

(C) 2017 The Authors. Published by Innovare Academic Sciences Pvt Ltd. This is an open access article under the CC BY license (http://creativecommons. org/licenses/by/4. 0/) DOI: http://dx.doi.org/10.22159/ajpcr.2017.v10i12.21003

\section{INTRODUCTION}

Heart is a continuously working organ. During cardiac myocyte metabolism, reactive oxygen species (ROS), and nitric oxide (NO) are produced in small amounts which are neutralized by the physiological antioxidant reserves such as reduced glutathione, catalase, and superoxide dismutase. Oxidative stress occurs when there is increased free radical generation in tissues or relative decrease in radical scavenging activity [1]. Free radical production is increased during chemical and radiation injury, ischemia-reperfusion injury, cellular ageing, and microbial killing by phagocytes. Thus, the oxidative stress to the working myocardial cells is increased during physical exertion, smoking, increased environmental temperature, pollution, irradiation, and infections. Much worsening scenario is the presence of pre-existing heart diseases and systemic disorders such as diabetes mellitus, hypertension, liver failure, lung diseases, and during cancer chemotherapy.

Cancer chemotherapy has been associated with many serious side effects and cardiotoxicity may be the dose-limiting factor [2]. Cyclophosphamide (CP) is a valuable antineoplastic agent in the treatment of acute and chronic leukemia, lymphoma, multiple myeloma, cancers of lung, breast, and ovary. This drug is also used as an immunosuppressant in rheumatoid arthritis and bone marrow transplantation [3]. However, CP is reported to cause multiple organ toxicities [4]. High doses used in the induction phase of chemotherapy can cause cardiotoxicity within 10 days of administration. The toxicity can manifest as mild blood pressure changes to myocarditis, fatal arrhythmia, tamponade, congestive heart failure, and acute hemorrhagic myocardial necrosis [3]. CP is an alkylating agent activated in the liver as phosphoramide mustard which alkylates and binds to DNA causing cross-linking and inhibition of protein synthesis. Increased generation of ROS and NO is believed to cause injuries to the working myocardial cells [5]. These impair cellular respiration and cause damage to the mitochondrial membrane leading to increased $\mathrm{Ca}^{2+}$ permeability [6]. The drug is non-cell cycle specific but also acts during DNA replication. The oxidative stress has been further increased by combination with other cardiotoxic anticancer and radiotherapy. Human studies with the scavengers such as acetylcysteine or tocopherol do not show any cardioprotective effect $[7,8]$. There have been research works all over the world to find out novel agents whether synthetic or plant-derived that can offer an acceptable level of cardioprotection from various insults both in the daily life and during chemotherapy [9].

Phyllanthus fraternus is a medicinal herb widely distributed in most tropical and subtropical countries. The plant belongs to Euphorbiaceae family [10]. Phytochemical analysis of plant extract reveals the presence of alkaloids, tannins, saponin, terpenoid, and steroid which are medicinally important bioactive compounds [11,12]. Aerial parts of the plant show greater antioxidant property by virtue of its higher polyphenolic content [13]. The plant also shows hepatoprotective effect against CP-induced mitochondrial dysfunction of liver cells [14], which may serve as a promising medicinal herb in complementary chemotherapeutic modalities. The present study aims to investigate the possible cardioprotective property of the plant against chemically induced toxicity using an animal model.

\section{METHODS}

Approval of Institutional Animal Ethics Committee (IEAC) Prior approval from the IAEC (Reg. No.: 1596/GO/a/12/Committee for the Purpose of Control and Supervision of Experiments on Animals [CPCSEA]) was obtained for the study. The number of animals used and the procedures conducted were approved by the IAEC in accordance with the regulations of CPCSEA. Animals were handled according to the suggested ethical guidelines for the care of laboratory animals during the experiment. 
Sample size

Sample size was 25 albino rats.

\section{Place of study}

The study was conducted in the Departments of Pharmacology and Pathology, Regional Institute of Medical Sciences, Imphal, from November 2014 to July 2016.

\section{Drugs and chemicals}

CP (CYPHOS ${ }^{\mathrm{TM}}$ ) was purchased from Getwell Pharmaceuticals, Haryana, India. Biochemical estimation and analyzing kits for CK, CK-MB and lactate dehydrogenase (LDH) were obtained from ERBA Transasia Diagnostics, Mannheim, Germany. For serum albumin, aspartate transaminase (AST) and alanine transaminase (ALT), the assay kits were purchased from Avantor Performance Materials India Ltd., Uttarakhand, India. All other chemicals and solvents used were of analytical grade. Standard pellet diets were procured from Amricon Agrovet Pvt., Ltd., marketed as Amrit feeds.

\section{Plant material}

The fresh plant of $P$. fraternus was harvested from the Lamphelpat Area, Imphal, Manipur, in the month of August. The plant was identified and authenticated by Dr. P. K. Singh, Professor, Department of Life Sciences, Manipur University, Imphal. A voucher specimen was kept in the University herbarium for reference (Voucher No. 000874).

\section{Preparation of extract}

The plant leaves were washed and shade dried. The leaves were powdered by mixer grinder and stored in an airtight container for future use. Preparation of aqueous extract was done by the method described by Verma and Agrawal [15]. The powdered leaves were extracted with distilled water using Soxhlet apparatus. The greenish-brown extract obtained was filtered, spread in an evaporating dish and dried on a hot water bath. The dried extract was scraped out, weighed and stored in glazed porcelain jar for use in the experiment. The yield was $13.5 \%$.

\section{Phytochemical screening}

Chemical tests were carried out using aqueous extract to identify various phytochemicals using standard methods [16,17]. The qualitative phytochemical analysis of AEPF revealed the presence of tannins, alkaloids, flavonoids, terpenoids, steroids, and saponins.

\section{Acute toxicity testing}

Acute toxicity test was carried out as per the OECD guidelines 423 [18] in female albino rats ( 3 rats per step). The rats were fasted for overnight with water ad libitum. Then, aqueous extract of $P$. fraternus (AEPF) was administered to the fasted rats at a dose of $300 \mathrm{mg} / \mathrm{kg}$ by a feeding tube. Food was withheld for further 3-4 hrs and observed once in every 30 min during the first 24 hrs and thereafter, daily for 14 days for any mortality. As there was no mortality, the procedure was repeated with a higher dose of $2000 \mathrm{mg} / \mathrm{kg}$ and animals were observed for mortality and toxic symptoms. It was observed that the dose of $2000 \mathrm{mg} / \mathrm{kg}$ p.o. caused no mortality or toxic symptoms among the tested animals and considered safe. Two doses of $200 \mathrm{mg} / \mathrm{kg}\left(1 / 10^{\text {th }}\right.$ of the maximum test dose) and $400 \mathrm{mg} / \mathrm{kg}$ of AEPF were fixed as working doses for the experiment.

\section{Selection of animals}

The young adult Wistar albino rats of either sex weighing 150-210 g procured from the Animal House, Regional Institute of Medical Sciences, Imphal, India, were used for the study. The animals were kept in polypropylene cages at room temperature under $12 \mathrm{hrs} \mathrm{light:} \mathrm{dark}$ cycle for 1 week in the animal room of the Department of Pharmacology, Regional Institute of Medical Sciences for acclimatization. They were fed with standard pellet diet with free access to water.

\section{Inclusion and exclusion criteria}

Baseline serum levels of CK, CK-MB, and LDH were estimated and normal reference ranges were calculated assuming the values are normally distributed [19]. The value ranges are of 100-140 IU/l, $\leq 8 \mathrm{IU} / \mathrm{l}$, and 115-192 IU/l, respectively. Animals with higher serum levels of these enzymes were excluded from the study groups.

\section{Experimental design}

In this study, treatment with AEPF at doses of 200 and $400 \mathrm{mg} / \mathrm{kg}$ body weight were selected as working dose based on acute toxicity data to assess the protection against myocardial toxicity associated with CP administration. The animals were divided into five groups (I, II, III, IV, and V) of 5 animals each. On day 1 , the Groups I and II animals were given $0.5 \mathrm{ml} / 100 \mathrm{~g}$ of normal saline (NS) intraperitoneally (i.p.) as a single injection. Similarly, Groups III, IV, and V animals were administered CP $(200 \mathrm{mg} / \mathrm{kg})$ mixed in NS at a volume of $0.5 \mathrm{ml} / 100 \mathrm{~g}$ i.p. Animals in Groups I and III were given 2\% gum acacia in distilled water at a dose of $1 \mathrm{ml} / 100 \mathrm{~g}$ orally for 10 days. Groups II and IV animals were made to receive $200 \mathrm{mg} / \mathrm{kg}$, and Group $\mathrm{V}$ animals received $400 \mathrm{mg} / \mathrm{kg}$ of AEPF suspended $2 \%$ gum acacia orally daily. AEPF was suspended in $2 \%$ gum acacia in distilled water in such a way that $1 \mathrm{ml}$ contained the calculated doses [Table 1]. Both control and treated animals were observed for 10 days after the last i.p. injection for the general appearance, behavior, and mortality.

\section{Blood collection}

To assess the baseline biochemical parameters, blood samples were drawn before any drug was given to the animals and again on the $11^{\text {th }}$ day after $24 \mathrm{hrs}$ of the last treatment. The animals were anesthetized with ether. Using glass capillary tube blood samples were collected from retro-orbital venous sinus [20]. About $2 \mathrm{ml}$ of blood from each animal were collected in a vacutainer from all groups and allowed to clot. The blood was then centrifuged at a speed of $3000 \mathrm{rpm}$ for 10 minutes. The serum separated was kept in a refrigerator at maintained temperature of $4^{\circ} \mathrm{C}$. It was used for biochemical estimation of the above-mentioned parameters. Ciprofloxacin eye drops were then applied to the eyes to prevent the development of infection after washing off the blood on the eye with cold saline.

\section{Biochemical estimations}

Serum creatine kinase (CK), CK isoenzyme MB (CK-MB), aspartate transferase (AST), alanine transferase (ALT), LDH, and albumin levels were estimated using commercially available kits as per the procedure described in the provided manual [21-26].

Relative heart to body weight ratio [27]:

Heart to body weight ratio $=\frac{\text { Weight of the heart }}{\text { Weight of the rat at the end of experiment }}$

Percentage of CK-MB in CK [28]:

$\%$ of $\mathrm{CK}-\mathrm{MB}=\frac{\text { Serum } \mathrm{CK}-\mathrm{MB} \text { activity }}{\text { Serum } \mathrm{CK} \text { activity }} \times 100$

\section{Histopathological preparation and scoring}

A midline abdominothoracic incision was performed under ether anesthesia. Heart tissues were quickly dissected out, washed in ice cold saline, dried with filter paper and weighed immediately. The tissues were fixed in $10 \%$ neutral buffered formalin for 48 hours. Cardiac tissues were prepared for histopathological examination using standard techniques [29]. Tissue sections (5 $\mu \mathrm{m}$ thick) of the ventricle portion of the hearts were prepared, stained with hematoxylin and eosin and observed under a light microscope for histopathological comparison among different groups of rats. The severity and extent of myocardial damage were observed for each case. The findings were classified into the following degrees, to compose a range of histologic myocardial injury: (0) No change, (1) mild - focal myocyte damage or small multifocal degeneration with slight degree of inflammation, (2) moderate - extensive myofibrillar degeneration and/or diffuse inflammatory process, and (3) severe - necrosis with diffuse inflammatory process [30]. 
Statistical analysis

The results of serum biochemical parameters were analyzed using oneway ANOVA followed by Dunnett's t-test using SPSS version 21. $\mathrm{p}<0.05$ was considered significant.

\section{Animal disposal}

The animal carcasses were buried deep in the ground covered with lime and disinfectants after the experiment [31].

\section{RESULTS}

Protective effects of AEPF against CP were established by observing the general behavior, body weight, heart weight, relative heart to body weight, cardiac biomarker enzymes, and cardiac histopathology at the end of the study period.

\section{General observations}

During the treatment period, normal and AEPF only treated rats showed good activity, normal feed and water consumption pattern. Their body weights increased at the end of the experiment. CP-treated animals developed a pinkish discoloration of foot paws and some dental abnormalities. Body hair becomes scruffy and sparse. The rats also had red exudates around the eyes and nose. On the $3^{\text {rd }}$ day, most of the CP-treated animals with or without extract coadministration developed lung crepitations. There was decreased food intake, activity and reaction to external stimuli and increased weakness. These conditions were more severe at the end of study period. No necrosis was observed at the i.p. injection site in all the groups.

\section{Body weight, heart weight, and relative heart to body weight}

$\mathrm{CP}$ treatment significantly decreased the body weight, increased the heart weight and heart to body weight ratio as compared to normal rats as shown in Table 2. Coadministration with AEPF significantly decreased the body weight loss, the heart weight and relative heart to body weight ratio. AEPF $400 \mathrm{mg} / \mathrm{kg}$ produced less increase in the heart weight when compared with $200 \mathrm{mg} / \mathrm{kg}$ dose $(\mathrm{p}<0.001)$.

\section{Cardiac biomarkers}

CP caused significant elevation of the levels of CK, CKMB, LDH, AST, ALT, and alkaline phosphatase (ALP) when compared with normal rats (Tables 3 and 4). AEPF treated Group IV and V rats showed significant $(\mathrm{p}<0.05)$ decrease in the serum levels of CK, CK-MB, LDH, AST, ALT, and ALP in dose-dependent fashion compared to CP treated group. Percentage of CK-MB in CK is also lessened in the extract treated group.

Table 1: Allotment of animals to different groups and their treatment

\begin{tabular}{lll}
\hline Groups & $\begin{array}{l}\text { Drugs given as } \\
\text { single dose i.p. }\end{array}$ & $\begin{array}{l}\text { Drugs given as single daily } \\
\text { dose p.o. for } \mathbf{1 0} \text { days }\end{array}$ \\
\hline I (normal) & $0.5 \mathrm{ml}$ of $0.9 \% \mathrm{NS}$ & $2 \%$ gum acacia at $1 \mathrm{ml} / 100 \mathrm{~g}$ \\
II (AEPF only) & $0.5 \mathrm{ml}$ of $0.9 \% \mathrm{NS}$ & AEPF susp. at $200 \mathrm{mg} / \mathrm{kg}$ \\
III (CP) & $\mathrm{CP}, 200 \mathrm{mg} / \mathrm{kg}$ & $2 \%$ gum acacia at $1 \mathrm{ml} / 100 \mathrm{~g}$ \\
IV (test 1) & $\mathrm{CP}, 200 \mathrm{mg} / \mathrm{kg}$ & $\mathrm{AEPF}$ susp. at $200 \mathrm{mg} / \mathrm{kg}$ \\
V (test 2) & $\mathrm{CP}, 200 \mathrm{mg} / \mathrm{kg}$ & AEPF susp. at $400 \mathrm{mg} / \mathrm{kg}$ \\
\hline
\end{tabular}

AEPF: Aqueous extract of Phyllanthus fraternus, i.p: Intraperitoneally,

CP: Cyclophosphamide
The serum albumin levels were significantly decreased in CP-treated rats when compared to normal rats. However, the AEPF treated groups showed significantly $(\mathrm{p}<0.05)$ increased levels of serum albumin when compared with CP treated group. However, the improved levels in AEPF treated groups were yet to reach the baseline levels.

\section{Histopathological observations}

The histology of the heart tissue of the normal control and AEPF treated animals showed normal myocardial syncytium and cellular morphological appearances (Fig. 1), whereas CP-treated group demonstrated hyperemic myocardial capillaries, loss of myofibrils, patchy necrosis, edematous cardiomyocytes, vacuolization of the cytoplasm, enlarged, and swollen mitochondria. However, inflammatory cell infiltration was not observed in these tissues. The histology of AEPF treated Group IV and V showed comparatively lesser damage to myofibrils and vacuolization of the cytoplasm. Histological scoring also showed maximum score in CP group. The scores decrease in test groups with a significant difference in Group V compared with CP only treated group (Table 5).

\section{DISCUSSION}

Phytochemical analysis of AEPF revealed the presence of active constituents such as phytosterols, flavonoids, triterpenoids, and tannins. DPPH radical scavenging assay depicted the total antioxidant activity of AEPF. Similar phytochemicals with antioxidant properties of plant species in the genus Phyllanthus, namely, Phyllanthus niruri, Phyllanthus urinaria, and Phyllanthus emblica have been reported in previous studies [32-35].These phytochemicals have been reported to have different functional properties such as scavenging of ROS, inhibition of free radicals generation and chain-breaking activity.

The CP treated rats showed a decrease in body weight and increase in heart weight. Decreased in the body weight might be due to the reduced food intake, intensive antimitotic activity and increased the rate of apoptosis of body cells [36]. Increase in the heart weight might be attributed to the loss of myofibrils, dilation of sarcoplasmic reticulum, swelling of mitochondria, and increased number of lysosomes [37]. These changes led to gross anatomical changes of the heart resulting in remodeling phenomena such as cardiac hypertrophy, ventricular dilation, and overall enlargement of the heart. Heart weight and ratio of heart weight to body weight findings in our study reflected these facts. AEPF treatment reduced the increment in heart weight and relative heart to body weight ratio.

The experimental study demonstrated that there was an increase in the serum enzyme activities of CK, CK-MB, LDH, AST, ALT, and ALP in $\mathrm{CP}$-treated rats. The findings suggested that $\mathrm{CP}$-induced oxidative stress caused leakage of cardiac biomarker enzymes due to its membranedamaging effect. Heart tissue is especially susceptible to free radical injury because of low reserve of myocardial tissue antioxidants and free radical detoxifying enzymes [38]. Cotreatment of AEPF with CP decreased the serum activities of these enzymes. This action of AEPF could be attributable to its phytoconstituents such as phytosterols, flavonoids, and terpenoids.

The serum CK, CK-MB, and LDH enzyme activities are important measures of both early and late phases of cardiac injury. Evaluation

Table 2: Changes in the body weight, heart weight and relative heart to body weight ratio of normal, CP and AEPF treated groups of rats

\begin{tabular}{lllll}
\hline Groups & Initial body weight $(\mathbf{g})$ & Final body weight $(\mathbf{g})$ & Heart weight $(\mathbf{g})$ & Heart to final body weight ratio $\left(\times \mathbf{1 0}^{-3}\right)$ \\
\hline I & $174.17 \pm 7.82$ & $190.83 \pm 6.94$ & $0.60 \pm 0.01$ & 3.14 \\
II & $172.00 \pm 4.60$ & $181.2 \pm 3.6^{+\dagger}$ & $0.60 \pm 0.02^{+\dagger \dagger}$ & $3.31^{++\dagger}$ \\
III & $183.80 \pm 9.70$ & $130.2 \pm 8.9^{* * *}$ & $0.76 \pm 0.01^{* * *}$ & $5.84^{* * *}$ \\
IV & $184.80 \pm 6.46$ & $144.6 \pm 8.09^{* *}$ & $0.72 \pm 0.01^{* * *+\dagger}$ & $4.98^{* * *}$ \\
V & $180.60 \pm 9.09$ & $152.0 \pm 10.43^{*}$ & $0.67 \pm 0.01^{* * *++t *}$ & $4.41^{*+}$ \\
\hline
\end{tabular}

Values are expressed as mean \pm SEM ( $\mathrm{n}=5$ ) one-way ANOVA (SPSS 21$),{ }^{*} \mathrm{p}<0.05,{ }^{* *} \mathrm{p}<0.01,{ }^{* * *} \mathrm{p}<0.001$ with respect to normal group; ${ }^{\dagger} \mathrm{p}<0.05,{ }^{+\dagger} \mathrm{p}<0.01$,

${ }^{++1} \mathrm{p}<0.001$ with respect to CP group; ${ }^{\ddagger} \mathrm{p}<0.001$ with respect to Group IV. Group I: Normal control; Group II: AEPF (200 mg/kg); Group III: CP (200 mg/kg);

Groups IV and V: CP + AEPF (200 and $400 \mathrm{mg} / \mathrm{kg}$, respectively). AEPF: Aqueous extract of Phyllanthus fraternus, CP: Cyclophosphamide 


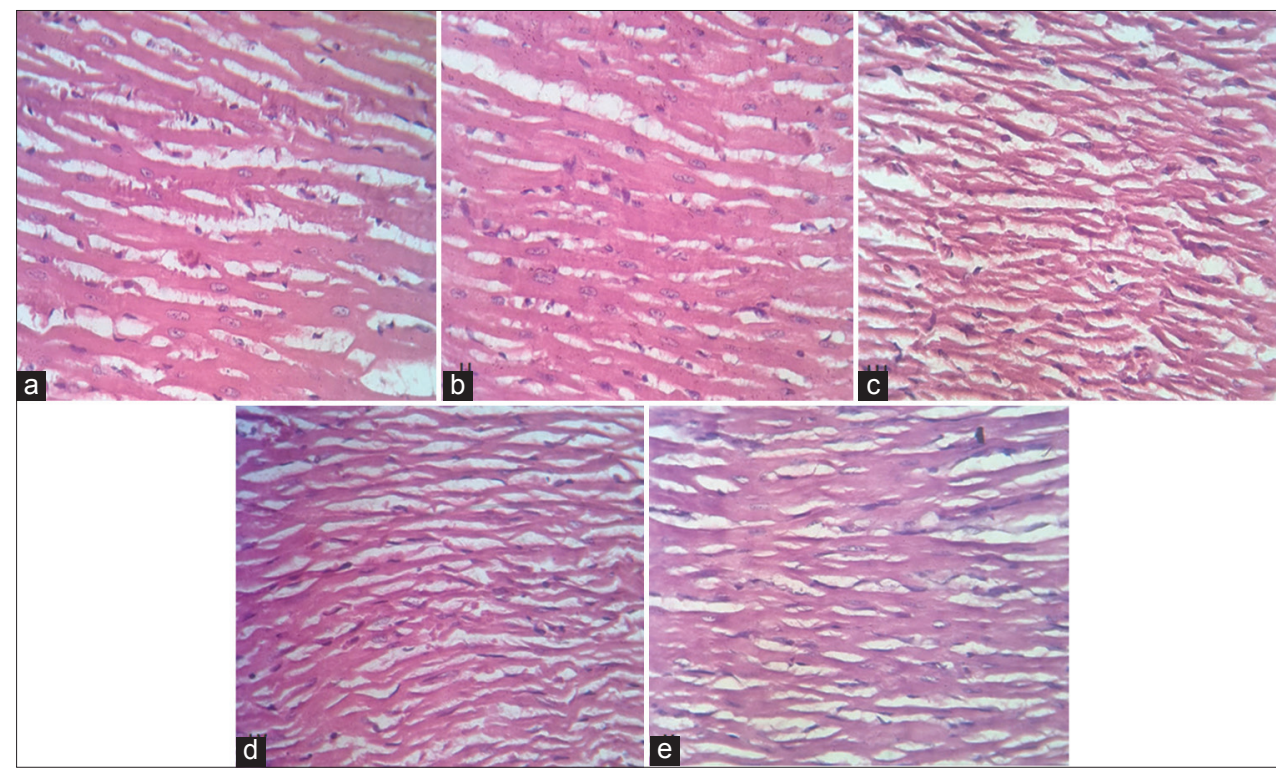

Fig. 1: Photomicrograph of heart tissues in (a) normal, (b) aqueous extract of Phyllanthus fraternus (AEPF) (200 mg/kg) treated, (c) cyclophosphamide (CP) $(200 \mathrm{mg} / \mathrm{kg})$ treated, (d) CP+AEPF $(200 \mathrm{mg} / \mathrm{kg})$ treated and (e) CP+AEPF $(400 \mathrm{mg} / \mathrm{kg})$ treated rats Stain: Hematoxylin and eosin $\times 40$

Table 3: Effect of AEPF leaves on serum cardiac marker enzymes and percentage of CK-MB in CP-induced cardiotoxicity in rats

\begin{tabular}{lllll}
\hline Groups & CK (IU/L) & CK-MB (IU/L) & Percentage of CK-MB & LDH (IU/L) \\
\hline Baseline & $119.68 \pm 9.63$ & $6.02 \pm 0.64$ & 5.57 & $153.8 \pm 18.9$ \\
I & $144.44 \pm 9.22$ & $6.41 \pm 0.88$ & 4.47 & $188.9 \pm 17.06$ \\
II & $132.06 \pm 15.44^{\dagger+}$ & $6.19 \pm 0.90^{\dagger \dagger}$ & $4.66^{\dagger \dagger}$ & $178.09 \pm 16.19^{\dagger \dagger}$ \\
III & $404.44 \pm 24.06^{* *}$ & $217.36 \pm 20.48^{* *}$ & $54.39^{* *}$ & $420.94 \pm 30.29^{* *}$ \\
IV & $305.40 \pm 21.04^{* *+}$ & $117.04 \pm 20.48^{* *++}$ & $39.47^{* *}$ & $339.99 \pm 30.29^{* *}$ \\
V & $231.11 \pm 16.5^{* *+\dagger \neq}$ & $44.98 \pm 4.3^{\dagger+\neq}$ & $19.93^{*+\dagger}$ & $242.85 \pm 25.60^{+\dagger}$ \\
\hline
\end{tabular}

Values are expressed as mean \pm SEM ( $n=5)$, one-way ANOVA followed by Dunnett's t-test (SPSS 21$),{ }^{*} p<0.05,{ }^{*} p<0.001$ with respect to baseline group; ${ }^{\dagger} p<0.01{ }^{+}{ }^{+} \mathrm{p}<0.001$ with respect to CP group; $\ddagger^{\mathrm{p}}<0.05$, ${ }^{\ddagger} \mathrm{p}<0.001$ with respect to Group IV; baseline Group: Before start of experiment; Group I: Normal control; Group II: AEPF (200 mg/kg); Group III: CP (200 mg/kg); Groups IV and V: CP + AEPF, 200 and $400 \mathrm{mg} / \mathrm{kg}$, respectively. CK: Creatine kinase, CK-MB: Creatine kinase isoenzyme-MB, LDH: Lactate dehydrogenase, AEPF: Aqueous extract of Phyllanthus fraternus, CP: Cyclophosphamide

Table 4: Effect of AEPF leaves on serum albumin and transaminases AST and ALT and AST/ALT ratio in CP-induced cardiotoxicity in rats

\begin{tabular}{llll}
\hline Groups & Albumin $(\mathbf{g} / \mathbf{d L})$ & AST $($ IU $/ \mathbf{L})$ & ALT (IU/L) \\
\hline I & $3.93 \pm 0.10$ & $29.10 \pm 3.68$ & $15.13 \pm 1.79$ \\
II & $3.93 \pm 0.14$ & $24.44 \pm 4.28^{+\dagger}$ & $17.80 \pm 4.63^{+\dagger}$ \\
III & $2.19 \pm 0.09^{* *}$ & $111.74 \pm 4.28^{* *}$ & $69.84 \pm 5.52^{* *}$ \\
IV & $2.83 \pm 0.105^{* *+}$ & $97.78 \pm 4.28^{* *}$ & $48.88 \pm 6.53^{* *}$ \\
V & $3.21 \pm 0.14^{*+\dagger}$ & $69.84 \pm 5.52^{* *+\dagger}$ & $31.43 \pm 6.53^{+\dagger}$ \\
\hline
\end{tabular}

Values are expressed as mean \pm SEM ( $\mathrm{n}=5$ ) one-way ANOVA (SPSS 21$),{ }^{*} \mathrm{p}<0.05,{ }^{* *} \mathrm{p}<0.001$ with respect to normal group; ${ }^{+} \mathrm{p}<0.05$, ${ }^{++} \mathrm{p}<0.001$ with respect to CP group; Group I: Normal control; Group II: AEPF (200 mg/kg); Group III: CP (200 mg/kg), Groups IV and V: CP + AEPF (200 and 400 mg/kg, respectively). AST: Aspartate transaminase, ALT: Alanine transaminase, AEPF: Aqueous extract of Phyllanthus fraternus, CP: Cyclophosphamide

Table 5: Histological scoring for severity of myocardial tissue damage

\begin{tabular}{ll}
\hline Groups & Histological scoring \\
\hline I & $0.50 \pm 0.22$ \\
II & $0.40 \pm 0.24^{\text {t十 }}$ \\
III & $2.80 \pm 0.20^{* *}$ \\
IV & $2.20 \pm 0.20^{* *}$ \\
V & $1.60 \pm 0.54^{* \dagger}$ \\
\hline
\end{tabular}

Values are expressed as mean \pm SEM (n=6) one-way ANOVA (SPSS 21), * $<<0.05$, ${ }^{* *} \mathrm{p}<0.001$ with respect to normal group; ${ }^{\dagger} \mathrm{p}<0.01,{ }^{+\dagger} \mathrm{p}<0.001$ with respect to CP group; Group I: Normal control, Group II: AEPF (200 mg/kg), Group III: CP (200 mg/kg), Groups IV and V: CP + AEPF (200 and $400 \mathrm{mg} / \mathrm{kg}$, respectively). AEPF: Aqueous extract of Phyllanthus fraternus

of these enzymes together gives a good correlation of myocardial injury [39]. Fraction of myocardial CK-MB isoenzyme activity in serum CK activity level gives an idea to the extent of myocardial damage contributing to total CK activity. In the test groups, i.e., groups treated with a combination of CP and AEPF, these enzyme levels were significantly decreased suggesting that AEPF protected the myocardial tissue against $\mathrm{CP}$ toxicity.

Serum albumin level correlates well with the metabolic status of the body. CP induces a state of increased catabolism as reflected by decreased in serum albumin level [40]. Coadministration of CP with AEPF improved the albumin level reflecting reduced catabolism and improved the nutritional status of the rats.

The elevations of serum transaminases such as AST and ALT have been associated with extensive hepatic and myocardial injury, the increased levels being proportional to the size of injury. The heart muscle is rich in both these enzymes, especially AST. A typical myocardial injury gives an AST/ALT ratio $>1[41,42]$. Therefore, the increased level of 
these enzymes can be considered an indicator of myocardial damage. The CP-treated group showed marked elevation in serum levels of AST and ALT as compared to the normal group. The result showed that CP, when given in high dose for short period of time, could cause both liver and heart injury. The observed AST/ALT ratio $>1$ in our study could be suggestive of more likely myocardial damage than hepatic injury. In the groups treated with both CP and AEPF, the AST and ALT levels significantly decreased as compared to CP only treated group. Therefore, the observations in the study suggested that AEPF might provide some degree of protection against myocardial damage.

ALP activity in endothelial cell surface is partly responsible for the conversion of adenosine nucleotides to adenosine, a potent vasodilator and anti-inflammatory mediator that can protect tissues from the ischemic damage [43]. Acrolein, an active metabolite of CP induces damage to endothelial cells of the vascular system leading to endothelial dysfunction and dysregulation of myocardial perfusion [44]. Deficiency of oxygen supply or metabolic substrates to the myocardial cells may damage the cell membrane resulting to leakage of enzymes. These changes could be accounted for by the elevation of ALP in the CP control group. Administration of AEPF improved the antioxidant status and therefore, provided protection against the damage to the endothelial cells.

The normal and AEPF-treated rats did not show any morphological changes in heart histology. CP produced massive cardiomyopathic changes in the myocardial syncytium showing a varying degree of changes in the cardiac muscle fibers mainly in the form of degeneration and necrosis of myocardial tissue, vacuolization of the cardiomyocyte sarcoplasm, swelling of mitochondria, and myofibrillar loss. Comparative study of histopathological sections of cardiac tissue from different rat groups showed that treatment with AEPF partially attenuated CPinduced cardiac damages. This cardioprotection was evident by fewer and less extensively swollen mitochondria and myofibril loss. The histopathological scoring of different treatment groups also depicted the extent and reversal of myocardial damage. However, no cellular inflammatory infiltrates were found in the sections of all the study groups. This might be attributed to the immunosuppressant effect of CP.

In this study, there are some limitations. The effect of CP and AEPF on electrocardiographic changes of heart has not been evaluated. Endogenous antioxidant levels in various treatment groups have not been determined. Staining of necrotic and infarcted myocardial tissue could have demonstrated comparative salvaging of the myocardium in control and treated groups in rats. Effect on other cardiovascular parameters such as blood pressure, heart rate, vasodilation, peripheral resistance, and antiplatelet activity could have been undertaken. However, the cardiac enzyme markers and heart histopathology provided a substantial assessment of cardioprotection offered by the plant.

\section{CONCLUSION}

The study showed improvement in the biochemical parameters and histological pictures in aqueous extract treated group conforming its cardioprotective role. However, further studies are needed to elucidate the exact mechanism of action of cardioprotection offered by its phytoconstituents and its clinical application to prevent or cure cardiac injury and dysfunction.

\section{ENCES}

1. Kumar V, Abbas AK, Fausto N. Cellular adaptations, cell injury, and cell death. In: Kumar V, Abbas AK, Fausto N, editors. Robbins and Cotran Pathologic Basis of Disease. $7^{\text {th }}$ ed. Philadelphia, PA: Elsevier; 2005. p. 3-46.

2. Schimmel KJ, Richel DJ, van den Brink RB, Guchelaar HJ. Cardio toxicity of cytotoxic drugs. Cancer Treat Rev 2004;30(2):181-91.

3. Goldberg MA, Antin JH, Guinan EC, Rappeport JM. Cyclophosphamide cardio toxicity: An analysis of dosing as a risk factor. Blood 1986;68(5):1114-8.

4. De Souza CA, Santini G, Marino G, Nati S, Congiu AM, Vigorito AC, et al. Amifostine (WR-2721), a cytoprotective agent during high-dose cyclophosphamide treatment of non-Hodgkin's lymphomas: A phase II study. Braz J Med Biol Res 2000;33(7):791-8.

5. Mythili Y, Sudharsan PT, Varalakshmi P. dl-alpha-lipoic acid ameliorates cyclophosphamide induced cardiac mitochondrial injury. Toxicology 2005;215(1-2):108-4.

6. Souid AK, Tacka KA, Galvan KA, Penefsky HS. Immediate effects of anticancer drugs on mitochondrial oxygen consumption. Biochem Pharmacol 2003;66(6):977-87.

7. Dorr RT. Chemo protectants for cancer chemotherapy. Semin Oncol 1991;18 1 Suppl 2:48-58.

8. Myers $\mathrm{C}$, Bonow R, Palmeri S, Jenkins J, Corden B, Locker G, et al. A randomized controlled trial assessing the prevention of doxorubicin cardiomyopathy by $\mathrm{N}$-acetyl cysteine. Semin Oncol 1983;10 1 Suppl 1:53-5.

9. Lobo V, Patil A, Phatak A, Chandra N. Free radicals, antioxidants and functional foods: Impact on human health. Pharmacogn Rev 2010;4(8):118-26

10. Webster GL. Classification of the Euphorbiaceae. Ann Mo Bot Gard 1994;81(1):3-32.

11. Mehta K, Patel BN, Jain BK. Phytochemical analysis of leaf extracts of Phyllanthus fraternus. Res J Recent Sci 2013;2:12-5.

12. Christian M. Steroids-chemical constituents of Phyllanthus fraternus Webster through TLC and HPTLC. Int Res J Chem 2013;1(1):29-48.

13. Upadhyay R, Chaurasia JK, Tiwari KN, Singh K. Antioxidant property of aerial parts and root of Phyllanthus fraternus Webster, an important medicinal plant. ScientificWorldJournal 2014;2014:692392.

14. Kumari KK, Setty OH. Protective effect of Phyllanthus fraternus against mitochondrial dysfunction induced by co-administration of cisplatin and cyclophosphamide. J Bioenerg Biomembr 2012;44(1):179-88.

15. Verma SC, Agarwal SL. Studies on Leptadenia reticulate: II. Preliminary chemical investigations. Indian J Med Res 1962;50:439-45.

16. Kokate CK, Purohit AP, Gokhale SB. Pharmacognosy. $43^{\text {rd }}$ ed. Pune: Nirali Prakashan; 2009.

17. Trease GE, Evans WC. Pharmacognosy. $11^{\text {th }}$ ed. London: Bailliere Tindall; 1989

18. OECD. OECD Guideline for Testing of Chemicals 423: Acute Oral Toxicity - Acute Toxic Class. Available from: https://www.ntp. niehs.nih.gov/iccvam/suppdocs/feddocs/oecd/oecd g1423.pdf. [Last accessed on 2013 Jul 14].

19. Kirkwood BR, Sterne JA. Essential Medical Statistics. 2 $2^{\text {nd }}$ ed. Massachusetts: Blackwell Science Ltd.; 2003.

20. Medhi B, Prakash A. Practical Manual of Experimental and Clinical Pharmacology. New Delhi: Jaypee Brothers Medical Publishers (p) Ltd.; 2010.

21. IFCC. Methods for the measurement of catalytic concentration of enzymes. Part-7; IFCC method for creating kinase. Int Fed Clin Chem 1989;1(3):130-9

22. Christenson RH, Ohman EM, Topol EJ, O'Hanesian MA, Sigmon KN, Duh $\mathrm{SH}$, et al. Creative kinase MM and MB isoforms in patients receiving thrombolytic therapy and acute angiography. TAMI study group. Clin Chem 1995;41:844-52.

23. Siekmann L, Bonora R, Burtis CA, Ceriotti F, Clerc-Renaud P, Férard G, et al. IFCC primary reference procedures for the measurement of catalytic activity concentrations of enzymes at 37 degrees C. International federation of clinical chemistry and laboratory medicine. Part 7. Certification of four reference materials for the determination of enzymatic activity of gamma-glut amyl transferase, lactate dehydrogenase, alanine aminotransferase and creative kinase accord. Clin Chem Lab Med 2002;40(7):739-45.

24. Schumann G, Bonora R, Ceriotti F, Férard G, Ferrero CA, Franck PF, et al. IFCC primary reference procedures for the measurement of catalytic activity concentrations of enzymes at 37 degrees C. International federation of clinical chemistry and laboratory medicine. Part 4. Reference procedure for the measurement of catalytic concentration of alanine aminotransferase. Clin Chem Lab Med 2002;40(7):718-24.

25. Bais R, Philcox M. Approved recommendation on IFCC methods for the measurement of catalytic concentration of enzymes. Part 8. IFCC method for lactate dehydrogenase (1-Lactate: NAD Oxidoreductase, EC 1.1.1.27). International federation of clinical chemistry (IFCC). Eur J Clin Chem Clin Biochem 1994;32(8):639-55.

26. Kennedy JW, Carey RN, Coolen RB, Garber CC, Lee HT, Levine JB, et al. Evaluation of Precision Performance of Clinical Chemistry Devices; Approved Guideline (EP5-A). In: Wayne, PA, editor. USA: The National Committee for Clinical Laboratory Standards; 1999.

27. Viswanatha Swamy AH, Patel UM, Koti BC, Gadad PC, Patel NL, 
Thippeswamy AH. Cardio protective effect of Saraca indica against cyclophosphamide induced cardio toxicity in rats: A biochemical, electrocardiographic and histopathological study. Indian J Pharmacol 2013;45(1):44-8

28. Galen RS, Reiffel JA, Gambino R. Diagnosis of acute myocardial infarction. Relative efficiency of serum enzyme and is enzyme measurements. JAMA 1975;232:145-7.

29. Durry RA, Wallington EA. Carleton's Histological Technique. $4^{\text {th }}$ ed. New York: Oxford University Press; 1967.

30. Klopfleisch R. Multipara metric and semi quantitative scoring systems for the evaluation of mouse model histopathology - a systematic review. BMC Vet Res 2013;9:123.

31. Sahni SK. Indian National Science Academy. Guidelines for Care and Use of Animals in Scientific Research. New Delhi: Bengal Offset Works; 2000.

32. Thippeswamy AH, Shirodkar A, Koti BC, Sadiq AJ, Praveen DM, Swamy $\mathrm{AH}$, et al. Protective role of Phyllantus niruri extract in doxorubicin-induced myocardial toxicity in rats. Indian $\mathrm{J}$ Pharmacol 2011;43(1):31-5.

33. Chularojmontri L, Wattanapitayakul SK, Herunsalee A, Charuchongkolwongse S, Niumsakul S, Srichairat S. Ant oxidative and cardio protective effects of Phyllanthus urinaria L. on doxorubicininduced cardio toxicity. Biol Pharm Bull 2005;28(7):1165-71.

34. Rajak S, Banerjee SK, Sood S, Dinda AK, Gupta YK, Gupta SK, et al. Emblica officinalis causes myocardial adaptation and protects against oxidative stress in ischemic-reperfusion injury in rats. Phytother Res 2004;18(1):54-60.

35. Shilali K, Ramachandra YL, Rajesh KP, Swamy BE. Assessing the antioxidant potential of Phyllanthus acidus bark extracts. Int J Pharm Pharm Sci 2014;6(6):522-31.
36. Kanno TY, Sensiate LA, Paula NA, Salles MJ. Toxic effects of different doses of cyclophosphamide on the reproductive parameters of male mice. Braz J Pharm Sci 2009;45(2):313-9.

37. Chalcroft SC, Gavin JB, Herdson PB. Fine structural changes in rat myocardium induced by daunorubicin. Pathology 1973;5(2):99-105.

38. Takacs IE, Matkovics B, Varga SI, Homolay P, Feer G, Seres T. Study of the myocardial antioxidant defines in various species. Pharmacol Res 1992;25:177-8

39. Shahana AR, Karale S, Kamath JV. Cardio protective effect of Mentha longifolia against cyclophosphamide-induced cardio toxicity in rats: A biochemical, electrocardiographic and histopathological study. Int J Pharm Pharm Sci 2016;8(9):214-7.

40. Le Bricon T, Gugins S, Cynober L, Baracos VE. Negative impact of cancer chemotherapy on protein metabolism in healthy and tumorbearing rats. Metabolism 1995;44(10):1340-8.

41. Madan S, Guthikonda K, Singal D, Pitchumoni C. Elevated serum transaminase ratio is a predictor of coronary artery disease even in absence of ST-elevation myocardial infarction. J Am Coll Cardiol 2014;12(63):A1391

42. Visser MP, Krill MT, Muijtjens AM, Willems GM, Hermens WT. Distribution of enzymes in dog heart and liver; Significance for assessment of tissue damage from data on plasma enzyme activities. Clin Chem 1981;27(11):1845-50.

43. Gallo RL, Dorschner RA, Takashima S, Klagsbrun M, Eriksson E, Bernfield M. Endothelial cell surface alkaline phosphatase activity is induced by IL-6 released during wound repair. J Invest Dermatol 1997;109(4):597-603.

44. Ross MK, Matthews AT, Mangum LC. Chemical atherogenesis: Role of endogenous and exogenous poisons in disease development. Toxics 2014;2(1):17-34 